\title{
The Status of Wood Products Supply and Demand in Ethiopia: A Review
}

\author{
Gonche Girma* \\ Ethiopian Environment and Forest Research Institute (EEFRI) \\ P.O.Box 24536 code 1000, Addis Ababa, Ethiopia \\ Tensaye Abate \\ Central Ethiopia Environment and Forest Research Center (CEEFRC) \\ P.O.Box Addis Ababa, Ethiopia
}

\begin{abstract}
This review paper focused on the Ethiopian wood products demand and supply situation in the current and future time period. Fuel wood and industrial round wood products were considered in this review paper. The reviewed paper showed that the wood demand in Ethiopia growing fast due to increasing of purchasing power, economic growth, middle class, urbanization and construction boom. In 2015, the fuel wood demand estimated about 120.4 million $\mathrm{m}^{3} \mathrm{RWE}$ and industrial wood estimated approximately 8.4 million $\mathrm{m}^{3} \mathrm{RWE}$. To meet the needs of the growing demand, a supply of 4.4 million cubic meters of industrial wood will need to close the gaps by the year 2033. Demand and supply gap of wood products showed high disparity and grow from time to time. The round wood gap estimated 1.8 million $\mathrm{m}^{3}$ in 2013 and 4.4 million $\mathrm{m}^{3}$ gap of supply by the year 2033 . The total volume of wood products demand estimated 1.2 million $\mathrm{m} 3 \mathrm{RWE}$ in 2015 and $13.9 \mathrm{~m}^{3} \mathrm{RWE}$ by the year 2040. In the past years most of wood product supplied from woodlot and natural forest by logging while now it decreases and substitute by import products. In 2015, the country imported 3.006 million $\mathrm{m}^{3} \mathrm{RWE}$ of different industrial wood products. The imported products worth nearly USD 182.53 million and the domestic production was estimated about 5.43 million $\mathrm{m}^{3}$ in 2015 . The low level of industrial wood supply from domestic production is compensated by a large volume of imports. Between the years 2000-2013, the country has been imported 170,721.3 tons and estimate worth of 159 million USD and the import bill will reach 3 billion USD by the year 2035 . The country also imported an average $65,680 \mathrm{~m}^{3} /$ year of different industrial wood products between the years $2007-2015$. The main imported wood products were sawn wood, plywood and furniture. Ethiopia export small quantity of wood products. The trade balance between import and export showed that a negative trade balance between the years 2007-2015. The total estimated amount of import was $120,000 \mathrm{~m} \mathrm{RWE}$ and export about $35,000 \mathrm{~m}^{3}$ RWE. To narrow down demand-supply discrepancy and substitution of import volume, encouragement of investment is a crucial solution in forestry.
\end{abstract}

Keywords: Demand, Export, Import, Supply, Trade balance, Wood product

DOI: $10.7176 / \mathrm{JESD} / 12-1-03$

Publication date: January $31^{\text {st }} 2021$

\section{Introduction}

Forest products enter into the world trade at all stages as primary, semi processed, processed, and manufactured products. As the world's economies are becoming increasingly open and interconnected, international trade flows of forest products are increasing continuously and are placed in the eighth position in the world (Erb et al., 2009).Demand for wood products is one of the main drivers of investment in the forest management. Although short-term market changes influence individual decision-making, long-term changes in demand have a greater influence on investments in forestry and forest industry at the aggregate level (FAO, 2009). Due to new technology and technology substitution influences the supply and demand of forest products. New products from woody biomass are emerging and certain conventional wood products are being substitute (McEwan et al., 2019).

At times in history, there have been concerns that demand for wood would be greater than the ability to supply it, but that concern has recently dissipated. The wood supply and demand situations have changed because of market transitions, economic downturns, and continue forest growth (Howard, 2011). Globally, demand for wood products mainly round wood is predicted to reach 6 billion $\mathrm{m}^{3}$ by 2050 , and will be the main driver for the expansion of industrial plantations (Barua et al., 2014). The reason for this increased demand are varied, but included wood consumption by booming economies such as India, China, and Brazil; increased population growth, illegal logging and land conversion for agriculture in tropical areas, which will result in the reduction of naturally forested areas and therefore an increased reliance on plantations(McEwan et al.,2019).

In the past fifty years, the consumption of wood products has grown rapidly in Africa than other regions of the world and findings suggested that the continent will increasingly become a large net importer of wood products rather than export Global Environmental Fund (GEF) (2013). Similarly, East African countries including Ethiopia have not received the desired attention for sustainable growth of forestry sector and results increasing of forest 
related products import (FAO, 2016).

Wood product market in sub-Sahara Africa is large and fast growing (Larinde et al., 2010). The export of processed wood products has been constrained mainly by factors such as poor quality of finished products, lack of information technology to access overseas market information, and government policies which are inconsistent with global trends (Larinde et al., 2010). As a result, in this region the forestry exports declined from $3.6 \%$ to $1.9 \%$ (Agrawal et al., 2013). With the exception of Kenya, South Africa, Swaziland, Tanzania, and Zimbabwe, all countries in this region import nearly all of their paper requirements (Larinde et al., 2010). There was also a tendency of increase in the importing of wood products in the region (Kastner et al., 2011). Similarly in any other sun-Saharan African countries, Ethiopia experienced problems of wood shortage (Lemenih and Kassa, 2014). To supplement the limited supply of wood products from domestic sources, the country is importing timber, plywood, panel products, furniture, etc., from abroad(Nigatu, 2004; Bekele, 2011; Lemenih and Kassa, 2014; Alem, 2015; Alem, 2016).

Ethiopia has more than a hundred year experience in production of wood and wood products. On the contrary, now a day this industry sector is not as measured as its age, due to internal and external problems (Birhan, 2014). In Ethiopia, the forest supply is not well advanced in technology and final Harvested Wood Products (HWP), with most HWP used for products with short lifespan, such as fuel wood. Raw material production is dominated by state forest enterprises on the one hand, and many smallholders on the other. The low productivity of the forest plantations managed by these groups presents an opportunity to boost the forest sector. Timber prices are among the highest in Africa, despite the potential to produce timber domestically (Bekele, 2011). Timber demand is rapidly increasing, because of the high growth rate of gross domestic product over the past decade; and appears a rapid timber supply gap in the country (World Bank, 2017).

In order to develop sustainable plantation in the country, it is important to understand wood demand and its supply for narrow down the gap. Based on this, the purpose of the wood products demand and supply review is to assess the current competitiveness of the wood product subsector and the main opportunities for improving the sector in the future. More specifically, this review paper proposed here is intended to carry out a critical investigation of the current and future scenarios of wood products in general, in particular wood products demand, supply, and import and export situation.

\section{Method}

The review was conducted using different, journal articles, reports, and analyzing national and other secondary data sources. Secondary data source from peer-reviewed articles, books, and annual reports, and published and unpublished documents.

\section{Wood products demand and supply in Ethiopia \\ 3.1 Wood products demand}

Wood product demand is growing fast in Ethiopia due to population growth, urbanization and economic growth (Lemenih \& Kassa, 2014). The construction sector, growth urbanization and urban population, and growing middle class is driving a rapid increase in demand for wood products and other volume of wood products(Lemenih \& Kassa 2014;FSR,2015). The estimated amount in the year 2010 showed that 85 million $\mathrm{m}^{3}$ of wood products needed in Ethiopia for different purposes. The total wood product demand in 2015 , measured by the volume of wood consumed in the country from both import and domestic production is approximately 130.3 million $\mathrm{m}^{3}$ round wood equivalent (RWE). Approximately $92.3 \%$ of this is in the form of wood fuel and the rest is in the form of industrial wood.

The largest wood-based consumption in Ethiopia is wood fuel (charcoal and firewood (WBISPP, 2004). The annual volume of wood harvested for fuel wood is approximately 120.4 million $\mathrm{m}^{3} \mathrm{RWE}$ which accounts 115.024 million $\mathrm{m}^{3}$ and 5.408 million $\mathrm{m}^{3}$ firewood and charcoal respectively (FSR, 2015). The other wood demand which is consumed by produced and imported is industrial wood. Industrial wood includes construction wood, furniture, paper and paper products, sawn wood, wood pulp, plywood, veneer wood, poles, particle boards, MDF, etc. Among the industrial wood, the demand of construction wood, furniture products, pulp and paper products, and utility poles estimated to be approximately 8.4 million $\mathrm{m}^{3} \mathrm{RWE}$ (FSR, 2015).

\subsection{Wood products supply}

In Ethiopia, wood and other forest products supply comes from domestic production and import. In the past about $85 \%$ of wood demand has been covered by indigenous timber species logged from natural forests and agro forest (Desalegn and Tadesse, 2010). In 2015 alone, Ethiopia imported 3.006 million $\mathrm{m}^{3} \mathrm{RWE}$ of various industrial wood products worth approximately USD 182.53 million, and the importation trend is increasing. In fact, it more than doubled between 2007 and 2015(FSR, 2015). The increasing dependence on import is a matter of serious concern for the forest sector in Ethiopia. The domestic industrial wood production was estimated to be approximately 5.43 million $\mathrm{m}^{3}$ in 2015. On the other hand, the FSR (2015) estimated total domestic production of industrial wood at 
approximately 7.4 million $\mathrm{m}^{3}$ RWE in 2013 . The bulk of this wood production comes from woodlots in the form of poles, used in both traditional and modern construction.

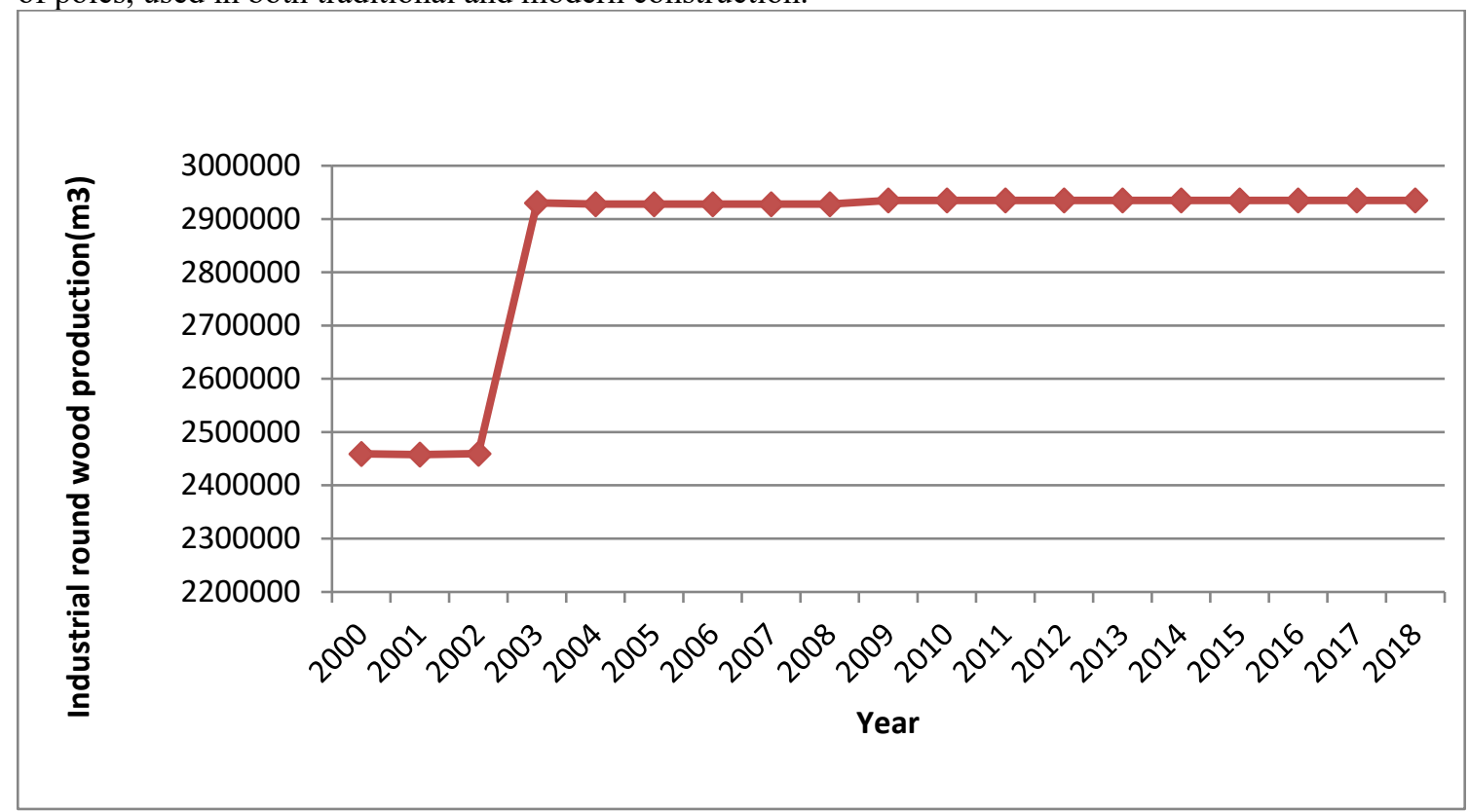

Figure 1: Domestic round wood production $\left(\mathrm{m}^{3}\right)$ in Ethiopia $(2000-2018)$

Source: FAOSTAT (2019)

The domestic industrial round wood production showed a constant growth from 2000-2001, high increment from 2002-2003 and declined trend from 2004 to 2018 as shown (Figure 1). This is supported by Kaba et al. (2018) investigated domestic production of wood in the country was showed declination duet forest resource of the country is limited and extracted with annual loss. Lemenih and Kassa (2014) also point out, Ethiopia experiences wood shortage from time to time and import huge quantity of wood products for supplement the growing demand.

\subsection{Demand and supply variance}

Forest products demand has been highly exceeding the supply where the gap has been still completed from import of forest products with hard currency while there are potential timber species (Kassa and Ewnetu, 2014). At the national level, there is a huge gap between demand and domestic sustainably produced supply of wood products (WBISPP, 2004; FSR, 2015). This has caused two economically unfavorable outcomes, First, it is driving unsustainable extraction of wood from the natural forests, and hence the degradation and loss of biodiversity. Second, this forces the country to depend heavily on imported wood products for its wood-based industries. Unless actions are taken quickly, the situation will drive further degradation of the natural stands and affect the economic growth of the country through competition for the scarce hard currency for importation of wood (Kassa and Ewnetu, 2014).

The gap in wood products supply from sustainable production including fuel wood demand is approximately 80 million $\mathrm{m}^{3}$ (FSR, 2015). This volume may reflect the illegal and unsustainable wood production from forest and woodland used mainly for fuel wood and some furniture. Including the import volume of wood, which is 3.124 million $\mathrm{m}^{3} \mathrm{RWE}$, about 83.124 million $\mathrm{m}^{3} \mathrm{RWE}$ is needed to ensure a properly and sustainably operating forest sector in Ethiopia (NFSDP, 2018). The sustainable supply from domestic sources on the other hand amounts only to 12 million $\mathrm{m}^{3}$ (Desalegn and Tadesse, 2010); hence a huge gap exist between demand and supply for wood products in the country. The FSR (2015) estimated 4.4 million $\mathrm{m}^{3}$ gap of supply by the year 2033, excluding fuel wood. This is converted to 310,000 ha of new well-managed forest stand. On the other hand, industrial round wood supply gap was estimated 1.8 million $\mathrm{m}^{3}$ in 2013 , mainly for construction and furniture industry wood products (MEFCC, 2017).

\subsection{Import and export balance of wood products}

\subsubsection{Import of wood products}

Ethiopia is the largest East African importer of wood products (ITTO, 2016). Imports have increased substantially since 2012 , driven by the booming economy and the country wide supply deficit of wood products. Key imported products are softwood sawn wood from Austria and wood based panels and joinery from China (UN comtrade, 2016).

The low level of industrial wood supply from domestic production is compensated by a large volume of 
imports. According to Getachew et al. (2015), the forest products imported amount and the corresponding hard currency value for the period between the years 2000-2013 has been 170721.3 tons costing 159 million USD. Kassa and Ewnetu (2014) pointed out that if no intervention measures are considered, the import bill by the year 2035 will reach about 3 billion USD. This importation of large wood products would demand the country a large foreign currency, which compromises the country's economic development.

FSR (2015) showed also Ethiopia imports a huge volume of industrial wood and the quantity of imports is growing continue. The country imported an average $65,680 \mathrm{~m}^{3} /$ year of various industrial wood products during the period 2007-2015. Sawn wood is the largest imported volume, on average $29,285 \mathrm{~m}^{3} /$ year, followed by plywood $\left(21,936 \mathrm{~m}^{3} /\right.$ year and particle board $\left(6,554 \mathrm{~m}^{3} /\right.$ year) (NFSDP, 2018). Plywood imports are showing rapid growth over recent years, reflecting growing demand for the product. This growth in demand is the reason for the rapid establishment of many small and medium-sized plywood factories in the country, resulting in a sharp increase in domestic production since 2013. Ethiopia paid USD 95.4 million for importing plywood during 2007-2015, an average of USD 10.6 million per annum. The largest country of origin for plywood imports is China. Ethiopia totally spends an estimated annual total of USD 183 million to import different wood products (FSR, 2015).

Imports include a significant amount of higher quantity of manufactured wood products such as furniture, paper and paper boards, wooden tools, joinery and carpentry products, boxes and cases and wooden furnishing (NFSDP, 2018). The average import weight of these products is 82,251 tons/year for the 2007-2015 periods. The largest import in this category is paper and paper board with the average of 70,403 tons/year, followed by 10,186 tons/year of furniture.

The average value of wood import amounts to approximately USD 123,898,000/year for the 2007-2015 period. The import bill is rapidly increasing over time. The products with the highest import value in decreasing order are: paper and paper board(USD 68,311,00/year); furniture(USD 19,205,00/year); sawn wood(USD 13,333,000/year) and Plywood (USD 10,593,000/year). Manufactured wood products together valued at over USD 100 million average annual import values since 2007. Major countries of origin for woods and wood products imported to Ethiopia are Austria, China, UAE, India, Turkey, Germany and Sweden (Birhan, 2014; NFSDP, 2018).

The trend of import showed that, Ethiopia spent millions of USD to import different wood products in different years (Birhan, 2014; Alem, 2016). The trend of expenses on the imported wood products into Ethiopia showed increase due to insufficiency of different wood production in the country depends on imported wood products to fill the demand and supply gap (Bekele, 2011; FAO, 2014;Alem, 2016). In addition to this, the country also spends high expenditure to import wood products due to lack of wood as a source of raw material and the presence of very few wood processing industries in the country (FAO, 2014; Alem, 2016; Bekele, 2011, Birhan, 2014).

\subsubsection{Export of wood products}

Ethiopia exports small quantities of various wood products (Alem, 2016). Among these products, Poles(536 3 /year), veneer(437 $\mathrm{m}^{3} /$ year), sawn $\operatorname{wood}\left(28,982 \mathrm{~m}^{3} /\right.$ year), furniture(98 tons/year), fuel wood/charcoal $\left(56 \mathrm{~m}^{3} /\right.$ year $)$ and chip wood $\left(21 \mathrm{~m}^{3} /\right.$ year $)$ are the main exports. Sawn wood is the product of high volume and value in terms of export (FSR, 2015). Plywood import and export data for the period of 2007-2015 shows only $48 \mathrm{~m}^{3}$ of exports compared to $197426 \mathrm{~m}^{3}$ of imports. The main destination is Sudan and Middle East countries. Ethiopia seems to be exporting low-quality, domestically produced sawn wood while importing sawn wood, which is of relatively better quality but expensive. Taking 1.54 RWE to produce $1 \mathrm{~m}^{3}$ of sawn wood, $20 \mathrm{~m}^{3}$ average volumes per hectare and a 10 years rotation period the country requires covering 22,550 ha of plantation for sawn wood production and importing substitution (NFSDP, 2018). A comparison of import and exports shows a negative trade balance, with a total volume of nearly $120,000 \mathrm{~m}^{3} \mathrm{RWE}$ import and about $35,000 \mathrm{~m}^{3} \mathrm{RWE}$ export; a net import balance of 3,079,074 $\mathrm{m}^{3} \mathrm{RWE}$ between 2007-2015 period (NFSDP, 2018). Ethiopia's import bill is hugely greater than the export revenue leading to a large negative trade balance. The negative trade balance doubled from -77,096,160 USD in 2007 to $-174,537,053$ USD in 2015.

\subsubsection{Wood product trade}

The Ethiopian wood products trade balance has a total volume of $110,000 \mathrm{~m}^{3}$ imports versus $24,000 \mathrm{~m}^{3}$ exports. Mean import products were sawn wood and wood-based panels, the major imports are roughly six times greater than exports. The wood products imported are of relatively high value, and the amount spent on imports could be invested in domestic resources and processing (NFSDP, 2018).

The domestic wood industries are serving both the local and international markets. Their production, excluding furniture, was estimated to value ranging from ETB 62.8 million in 2005 to ETB 163.8 million in 2009 , registering an average annual growth rate of $27.1 \%$ (Feyissa et al., 2011). Out of this, products valued about ETB 19.3 million were exported, while the balance supplemented with import was consumed in the local market (Feyissa et al., 2011). The contribution of import was significant during the period of 2005-2009. Total import excluding, furniture, increased from ETB 169.5 million in 2005 to ETB 489.4 million in 2009 corresponding to a yearly average growth rate of $30.3 \%$. Though, imports showed that continuous increase over the period from 2005 to 2013 (FAO, 2014; Alem, 2016; World Bank, 2017). There was a tendency to shift from one wood product to 
another wood product. For instance, in 2009 some wood products disappeared from the market to be replaced other wood products. In general import continued to appreciation the market covering on the average about $78 \%$ of the domestic market (Feyissa et al., 2011).

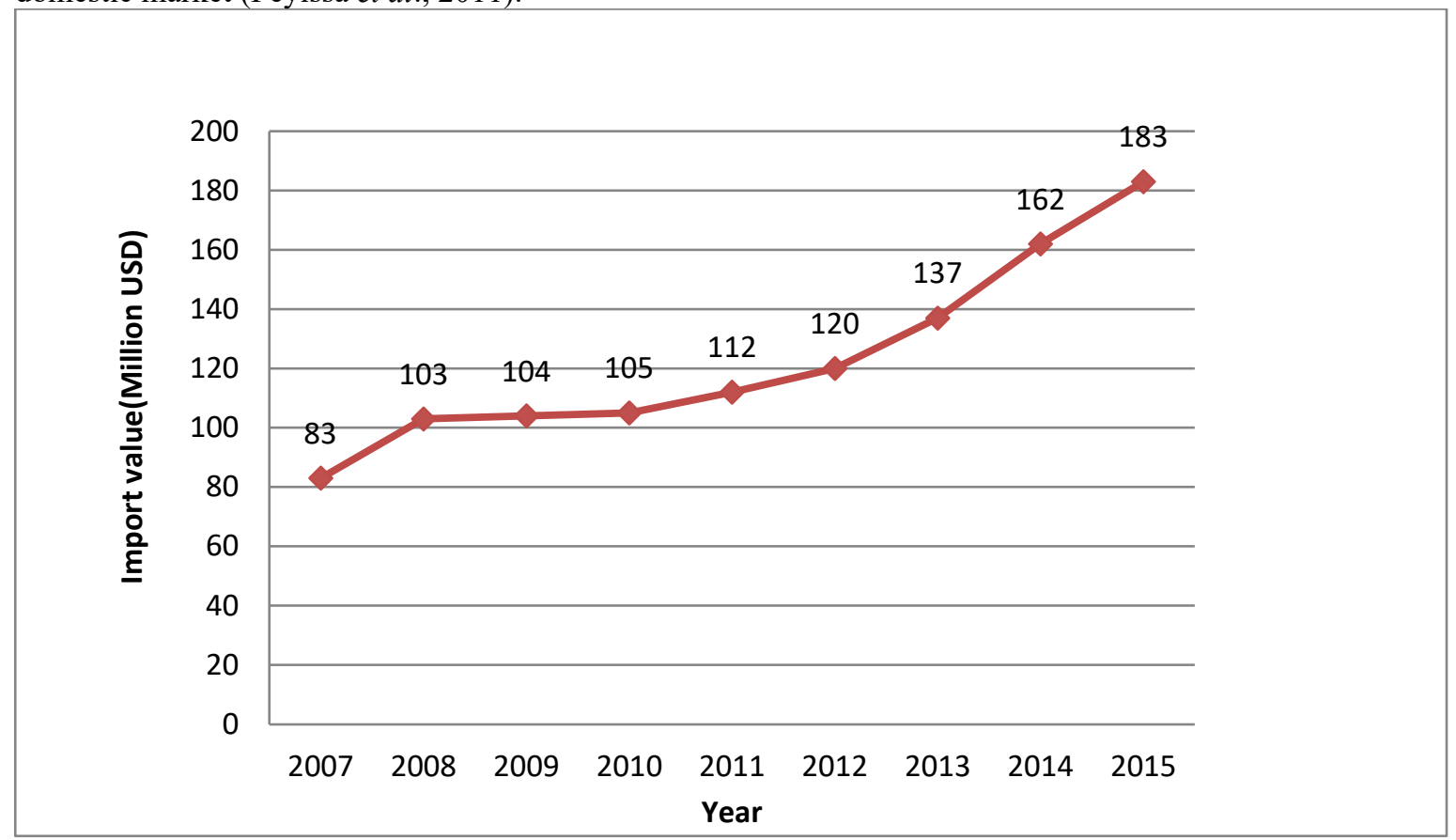

Figure 3: Trend in industrial wood import bill (USD) for wood based products in Ethiopia Sources: ECRA data (source: NFSDP, 2016)

\subsection{Furniture sector}

Demand for wooden furniture is a high value adding sub-sector which expected to grow by approximately $400 \%$ by the year 2033(FSR, 2017). Total furniture demand was estimated about 0.8 million $\mathrm{m}^{3}$ in 2013 and projected to increase about 1.8 million $\mathrm{m}^{3}$ by the year 2033. The small-scale wood industries in Ethiopia are dominantly found in the form of furniture, joinery and carpentry cottages (INDUFOR, 2016). In general small and cottage furniture manufacturing firms have increased in number (according to the industrial census) over the last ten years from about 8500 units to about 17,700 units and employment engagement from 23000 persons to 290000 persons contributing significantly to furniture production (INDUFOR, 2016). Large and medium-sized furniture manufacturing firms numbered about 330-350 (CSA, 2013). They are mostly located in Addis Ababa, SNNPR, Orormia, and Amhara regions. They are mostly owned by individual persons, with cooperatives and private limited firms as the next prevalent ownership arrangements.

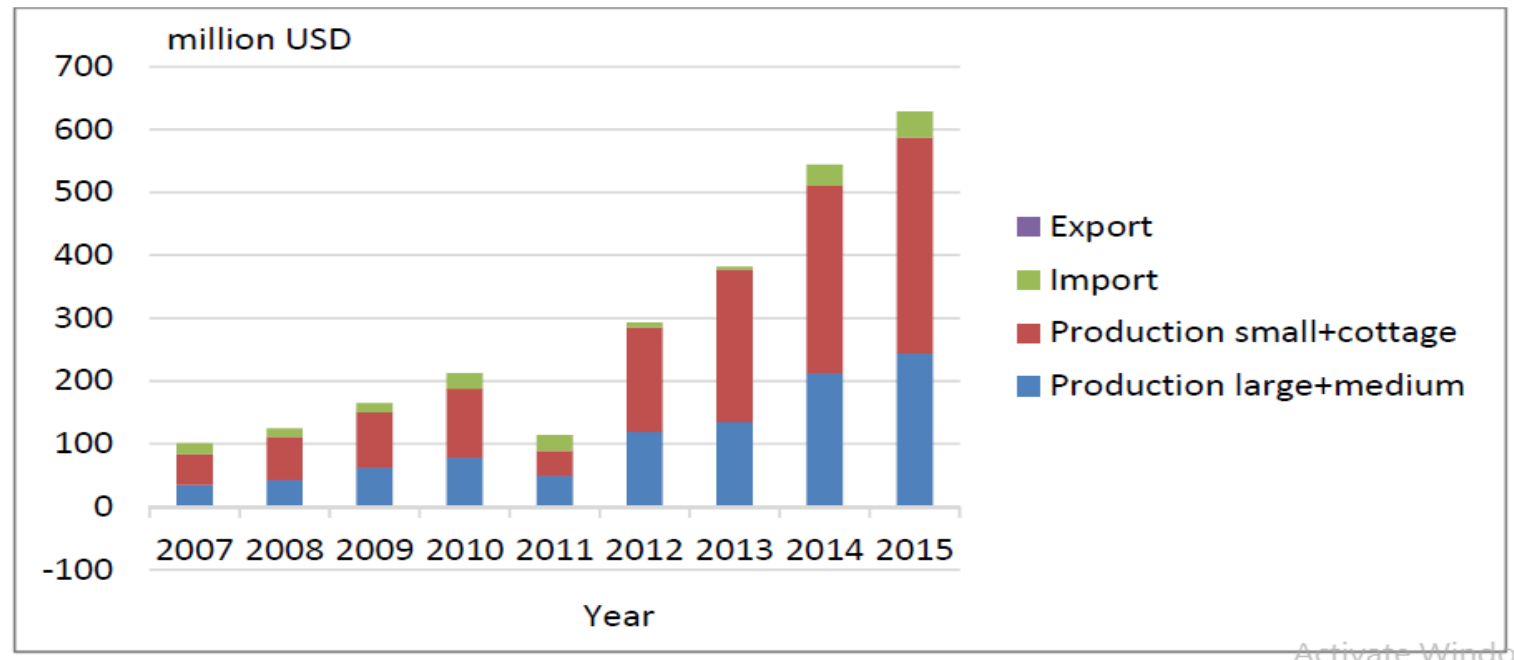

Figure 4: Furniture import-export and production trend

Source: INDUFOR, (2016)

The East African furniture imports come almost totally from outside of Africa in 2013. Ethiopia has emerged 
as the largest importer with a trade value of USD 43 million, followed by Kenya with USD 39 million as showed in (ITTO, 2016). In Tanzania the level is about USD 30 million, in Mauritius USD 16 million and Uganda USD 11 million. In the other countries (Somalia, Djibouti, Seychelles and Madagascar), the value of import is in the range of USD 3 to 5 million in 2013.

\subsection{Projection of demand and supply of wood products}

The demand of HWP (sawn wood, wood-based panels, paper and paper board, and other industrial round wood) will grow from 4.1 million $\mathrm{m}^{3}$ in 2013 to 16.7 million $\mathrm{m} 3$ in 2040(World Bank, 2017). The supply of HWP is estimated by considering anticipated growth of state forest enterprises, the Oromia Forest and Wildlife enterprise (OFWE), and the Amhara Forest Enterprise (AFE), as well as the growth of private woodlots, increasing demand will result in projected industrial round wood supply gap of 13.3millionm3 by 2040 (MEFCC,2017). The future supply gap could be addressed by establishing an additional 750,000 hectares of professionally managed productive forests $(400,000$ hectares long rotation to supply sawn wood plus $50 \%$ of other industrial round wood due to the demand for poles in intermediate dimensions, and 350,000 hectares to supply pulp for paper, woodbased panels, and 50\% of other industrial round wood) (FSR, 2017). Although the Government of Ethiopia has set objectives for increasing plantations for pulp and paper production in GTP1, conditions in the country will make it difficult for the industry to develop quickly (World Bank,2017; FSR,2017).

According to Alem (2016), Ethiopia will spend on average about USD 1 to USD 990.8 by the year 2024. The total expense of those different processed wood products imported from abroad estimated on average about USD25.5 million per year. The trend in general indicated that the average yearly expense to import for plywood and chipboard will decrease by 2024 relatively from the years of 2005-2013 (Alem, 2016).The FSR (2015) predicted an increase in the demand for furniture closed to $400 \%$ in 2033 , while another similar study predicted a demand growth of 477\% for industrial woods by 2040(INDUFOR, 2016 unpublished).

Table 1. Industrial wood demand in Ethiopia between 2015 and 2040 by product type

\begin{tabular}{lll}
\hline Product type & \multicolumn{2}{l}{ Demand in $\mathbf{R W E}\left(\mathbf{m}^{\mathbf{3}}\right)$ by period } \\
\cline { 2 - 3 } & $\mathbf{2 0 1 5}$ & $\mathbf{2 0 4 0}$ \\
\hline Sawn wood & 633,000 & $2,200,000$ \\
Plywood & 11,700 & 715,000 \\
Veneer and particle board & 91,700 & 88,500 \\
MDF & 12,000 & 375,000 \\
Furniture & 69,996 & $7,699,560$ \\
Utility poles & 40,000 & 500,000 \\
Pulp & 5,500 & 20,000 \\
Paper and paper board & 357,590 & $2,383,900$ \\
\hline
\end{tabular}

Source: FSR, 2015 and IFC study, 2016

The demand forecast indicates the volumes of wood products demanded by the Ethiopian market in the future. However, the forecast does not predict from where those products will be sourced either from domestic production or imported. Total volume of wood products demand specified in Figure 5 is estimated to be approximately 13.9 million $\mathrm{m}^{3}$ RWE by the year 2040 compared to 1.2 millionm $^{3}$ RWE wood demands in 2015 .

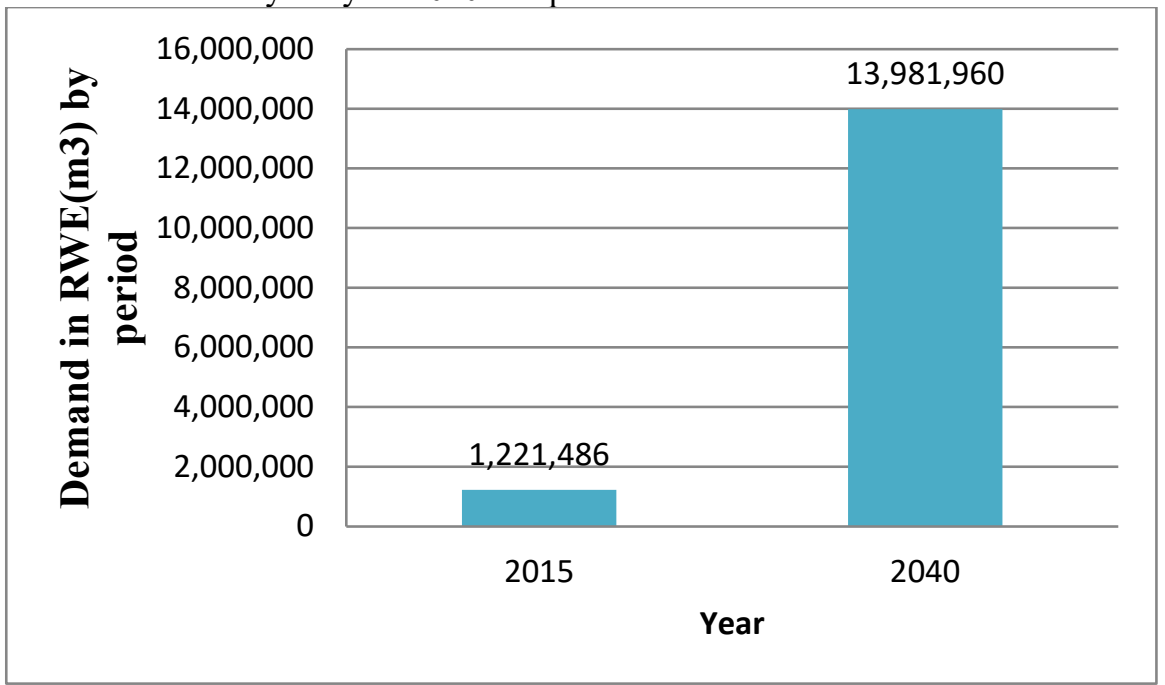

Figure 4: Projected round wood demand in 2015 and by 2040

Source: FSR, 2015 and IFC study, 2016, INDUFOR (2016) 


\subsection{Factor of demand and supply variance}

In Ethiopia, the rise of population, booming of construction sector and economic growth increase the demand for wood products for construction and wood fuel consumption (NFSDP, 2018; Kaba et al., 2018). At the same time, the forest resource of the country is limited and extracted with annual average loss of 91,000 ha from 2000 to 2013 (MEFCC, 2016). The wood product gap estimates indicate 38.9 million $\mathrm{m}^{3}$ in 2013(MEFCC, 2015).

In the furniture sector, the demand for furniture is derived by purchasing power, growing of middle age class and total population growth especially urban households (fast growing of urban households) which tend towards more furniture consumed per capita (Birhan, 2014; MEFCC, 2017).

\section{Conclusion and Recommendation}

\subsection{Conclusion}

The projection of different literatures in the review paper showed that, demand for wood products will continue to increase for the foreseeable future. Demand for wood products is met both from domestic production and import. Natural forest resources have declined and this trend expected to continue in the future if no action will be taken. Forest plantations will alleviate potential future wood supply for solving the existing wood shortage. In order to supply Ethiopia's growing wood product demand with sustainable domestic production, significant investments in plantations and wood-processing are required. The wood product sub-sectors are expected to have the largest supply gaps and provide promising business opportunities for private sector investment. In the Ethiopian market context, there a high discrepancy between demand and supply of wood products due to population and economic growth. The implication shown from the reviewed paper regarding to demand and market outlook for wood products, there is a need to increase industrial round wood supply through domestic production. Based on this, investment in the forest sector provides the opportunity to increase the contribution of the sector to national economy of the country through import substitution. Beyond this, the expansion of industrial round wood supply can generate hard currency from export opportunities of different processed wood products.

As the result of wood demand and supply discrepancy, Ethiopia import large quantity of wood and wood products from different countries in order to fill this gap. Regarding to export, the country outflow small quantity of different wood products compared with import amount. The discrepancy between import and export bill is very high indicating the negative trade balance. The demand and supply gap due to fast growth of demand as well as the negative trade balance in the country can take as an opportunity to invest in the forestry sector for narrowing down the demand-supply gap and the negative trade balance in wood sector.

For narrow down supply-demand gap and import-export variation, significant investment is needed in forestry sector by substituting the current import domination and unsustainable domestic wood production. It is important to transfer the amount of spent on import to wood production and processing investment.

\subsection{Recommendation}

Demand side policy: the government should ensure domestic enterprises which contribute to significance share of the growing wood demand in the country through encouraging investments in forest management and industrialization of the sector, etc. It is important to ensure continued focus on driving higher productivity and quality in large scale plantation with fast growing species. From policy perspective, there is a need to ensure that there is an aligned vision for the market actors can all contribute to the creation of competitive sector. Invest forest industry by engaging private sector on different sub-sectors such as furniture, construction wood sector, etc. by linking plantation activities. Research on wood demand and supply forecasting in order to take action for narrowing down the gap. Work on establishment of business enterprise network between tree growers and timber producers. Introducing of advanced wood product technology in order to produced competitive wood products. Draw lessons about the success of forestry sector from other East African countries experience like Kenya, Tanzania, Uganda, etc.

\section{Reference}

Agrawal, A., Cashore, B., Hardin, R., Shepherd, G., Benson, C., \& Miller, D. (2013,). Economic contribution of forests: Background paper prepared for the United Nations forum on forests. Paper presented at the United Nations Forum on Forests, Istanbul, Turkey.

Alem, S. (2015). International trade of different forest products in Ethiopia. African Journal of

Alem, S. (2016). Status and trends of the processed wood products trade in Ethiopia. Journal of Sustainable Forestry, 35(4), .251-260.

Barua SK, Lehtonen P., Pahkasalo T. (2014). Plantation vision: potentials, challenges and policy options for global industrial forest plantation development. Int For Rev 16:117-127.

Bekele, M., (2011). Forest plantations and woodlots in Ethiopia. In Afr. For. Forum Work. Pap. Ser (Vol. 1, pp. $1-51)$.

Birhan, G., (2014).Compititevness Analysis of Ethiopian Furniture Industry. (Unpublished MA Thesis). Addis 
Ababa University.

CSA 2008/2009 and 2012 Retail Price at Addis Ababa Term inal Market, Addis Ababa.

Desalegn, G. and Tadesse, W., (2010). Characteristics and Potential Uses of Eucalyptus Timber Species Grown in Ethiopia. Eucalyptus Species Management, History, status, and Trends in Ethiopia, 15, p.29.

Economic and Sustainable Development, 4(4), 353-361. doi:10.1504/AJESD.2015.072703

Erb, K. H., Krausmann, F., Lucht, W., \& Haberl, H. (2009). Embodied HANPP: Mapping the spatial disconnect between global biomass production and consumption. Ecological Economics, 69,328-334. doi:10.1016/j.ecolecon.2009.06.025

Ethiopian Forestry Society report, 2014: The Economic Significance and Trade of Forest and Forest Products in Ethiopia (cleared for inclusion in sub-regional publication for East Africa)

Ethiopian Forestry Society report., (2014): The Economic Significance and Trade of Forest and Forest Products in Ethiopia (cleared for inclusion in sub-regional publication for East Africa)

FAO.,(2016). Forestry Contribution to National Economy and Trade in Ethiopia, Kenya and Uganda. By Kilawe, E. and Habimana, D. Addis Ababa, Ethiopia

FDRE (2007) .Forest envelopment, conservation and utilization Proclamation Number 542/2007.The Federal Democratic Republic of Ethiopia, Addis Ababa, Ethiopia

Feyissa, S. and Garomsa, T., (2011). Narrowing trade deficit through increased import substitution. Chamber of Commerce and Sectoral Association.

Food and Agriculture Organization of the United Nations (FAO). (2007). State of the world's forests report. Rome, Italy: FAO Forestry Department.

FSR,(2015). Forest sector review focus on commercial forestry and industrialization, Addis Ababa, Ethiopia.

Getachew, D., Seyoum, K. and Daniel, G.,(2015). Forest products utilization Research in Ethiopia: Highlights on major Achievements and contributions. Ethiopian Environment and forest Research Institute, Addis Ababa.

Global Environment Fund (GEF). (2013). Africa will import—not export—wood. Chevy Chase, MD: Author.

Howard, J.L. and McKeever, D.B., (2011). US forest products annual market review and prospects, $2007-2011$. US Department of Agriculture, Forest Service, Forest Products Laboratory.

ITTO.(2016). Intra-African Trade in Tropical Timber and Timber Products and options for Trade facilitation

Kaba, G., Bekele, T. and Limenih, M., Actual and Potential Industrial Uses of Eucalyptus Wood in Addis Ababa, Ethiopia.

Kassa, H. and Ewnetu, Z., (2014). The importance of forestry in Ethiopia and the need for investing in the sector to meet national goals and international commitments (unpublished report)

Kastner, T., Erb, K. H., \& Nonhebel, S., (2011). International wood trade and forest change: A global analysis. Global Environmental Change, 21(3), 947-956.

Larinde, S. L., Akande, J. A., Agbeja, B. O., \& Ntabe, E. (2010). Prospects for wood products trade under the new partnership for Africa's development. Journal of Agriculture and Social Research,10, 7-16.

Lemenih, M. and Kassa, H., (2014). Re-greening Ethiopia: history, challenges and lessons. Forests, 5(8), pp.18961909.

McEwan, A., Marchi, E., Spinelli, R. and Brink, M., 2019. Past, present and future of industrial plantation forestry and implication on future timber harvesting technology. Journal of Forestry Research, pp.1-13.

MEFCC (Ministry of Environment, Forest and Climate Change) (2015) Ethiopia Forest Sector Review focus on commercial forestry and industrialization, Addis Ababa, Ethiopia.

MEFCC (Ministry of Environment, Forest and Climate Change) (2017) Forest change detection and emissionreduction, Addis Ababa, Ethiopia.

MEFCC(2018).National Forest Sector Development Program, Ethiopia Volume II: Program Pillars, Action Areas and Targets 2018

Million, B., 2011. Forest plantations and woodlots in Ethiopia. In African Forest Forum (Vol. 1, No. 12, pp. 11$15)$.

Million, B., 2011. Forest plantations and woodlots In Ethiopia. A platform for stakeholders in African forestry. African Forest Forum. Working Paper Series.

Ministry of Environment, Forest and Climate Change, 2017. Ethiopia Forest Sector Review(FSR).

NFSDP,(2018).National Forest Sector Development Program, Ethiopia Volume II: Program Pillars, Action Areas and Targets 2018

Nigatu, A., (2004). Sawn wood market of Addis Ababa (Master's thesis). Wondo Genet College of Forestry, Awassa, Ethiopia and the Swedish University of Agricultural Sciences, Skinnskatteberg, Sweden.

The Federal Democratic Republic of Ethiopia Central Statistical Agency (CSA) (2010). Report on Large and Medium Scale Manufacturing and Electricity Industry Survey, December 2009/10, Addis Ababa and Premium report, 2010

UNIQUE, (2016). Ethiopia Forest Sector Review. Final Report, Addis Ababa.

World Bank., (2017). Harnessing the Potential of Productive Forests and Timber Supply Chains for Climate 
Change Mitigation and Green Growth Opportunities for Private Sector Engagement World Bank.,(2011). Comparative Value Chain and Economic Analysis of the Furniture/Wood Processing Sector (Chairs) in Ethiopia, Tanzania, Zambia, China and Vietnam 